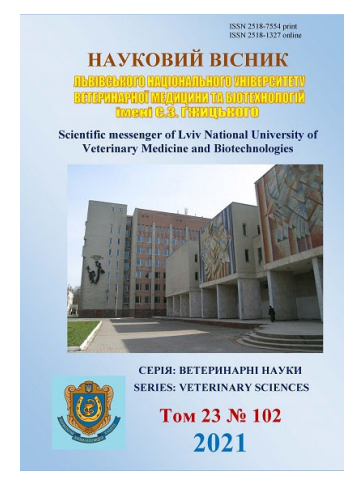

\section{Науковий вісник Дьвівського національного університету ветеринарної медицини та біотехнодогій імені С.3. Гжицыкого. Серія: Ветеринарні науки}

\author{
Scientific Messenger of Lviv National University \\ of Veterinary Medicine and Biotechnologies. \\ Series: Veterinary sciences
}

doi: $10.32718 /$ nvlvet10203 https://nvlvet.com.ua/index.php/journal

UDC 636. 4.053:612 - 017:612

\title{
Effect of stress on performance and physiological functions in pigs
}

\author{
L. Stovbetska, O. Poroshinska, M. Nischemenko, S. Shmayun, A. Emelyanenko, V. Koziy \\ Bila Tserkva National Agrarian University, Bila Tserkva, Ukraine
}

Article info

Received 26.02.2021

Received in revised form 29.03.2021

Accepted 30.03.2021

Bila Tserkva National Agrarian University, Pl. Soborna $8 / 1$,

Bila Tserkva, Kyiv region, 09117, Ukraine.

Tel.: +38-099-610-13-50

E-mail: liudmyla.stovbetska@btsau.edu.ua
Stovbetska, L., Poroshinska, O., Nischemenko, M., Shmayun, S., Emelyanenko, A., \& Koziy, V. (2021). Effect of stress on performance and physiological functions in pigs. Scientific Messenger of Lviv National University of Veterinary Medicine and Biotechnologies. Series: Veterinary sciences, 23(102), 14-23. doi: $10.32718 /$ nvlvet10203

In recent decades, the intensity of the use of pigs has increased significantly. In such conditions, the body of animals is used almost to the limit of its capabilities. In this regard, the administration of many physiological functions is disrupted, the morbidity and decrease in the performance of pigs significantly increase. The increase in the level of drug use does not solve these issues. For example, the uncontrolled use of antibiotics can lead to even more significant problems - the development of antibiotic resistance. Despite this, in modern pig breeding, considerable attention is paid to the development and implementation of methods for the prevention of diseases in pigs. An important component of such activities is to ensure optimal conditions for the comfort and well-being of animals. This, in turn, implies a reduction in the negative impact of stress factors in raising and fattening pigs. The aim of our research was to get acquainted with modern literature data on the features of the influence of stressors on productivity and physiological functions of pigs. During the writing of this review article, we reviewed data from current research on the effects of stressors on the productivity and physiological functions of pigs in rearing and fattening. For this purpose, the funds of the scientific library of Bila Tserkva National Agrarian University, scientific research systems Science-Direct and PubMed were used. An important task of veterinary service of modern pig breeding complexes is to ensure optimal parameters of the microclimate, feeding quality feed, reducing the negative impact of stress factors. Ensuring proper housing conditions contributes to the improvement of qualitative and quantitative indicators of pig productivity (at slaughter, during slaughter, etc.). In this regard, we believe that a promising area of research is to study the effects of certain stressors and their combinations on the body of pigs and find methods to correct them.

Key words: stress, pigs, behavior, performance, methods, conditions.

\section{Вплив стресу на продуктивність та фізіологічні функції свиней}

\author{
Л. С. Стовбецька, О. А. Порошинська, М. П. Ніщеменко, С. С. Шмаюн, А. А. Смельяненко, В. І. Козій
}

Білочерківський наиіональний аграрний університет, м. Біла Церква, Украйна

\footnotetext{
В останні десятиліття інтенсивність використання свиней значно збільшується. В таких умовах організм тварин використовується практично на межі свойх можливостей. У зв'язку з ичим порушується координація багатьох фізіологічних функиій, значно підвищується захворюваність та знижуються показники продуктивності свиней. Підвищення рівня використання лікарських засобів не дозволяє вирішити ці питання. Наприклад, неконтрольоване використання антибіотиків може призводити до появи ще серйозніших проблем - розвитку антибіотикорезистентності. Зважсаючи на це, у сучасному свинарстві значна увага приділяється розробиі та впровадженню методів профілактики захворювань свиней. Важливою складовою таких заходів $є$ забезпечення оптимальних умов комфорту та добробуту тварин. Це своєю чергою передбачає зниження негативного впливу стресових факторів під час вирошування та відгодівлі свиней. Метою нашого дослідження було ознайомлення з сучасними літературними даними про особливості впливу стресових факторів на продуктивність та фізіологічні функиії свиней. Під час написання цієї оглядової статті ми ознайомилися з даними сучасних наукових досліджень щодо впливу стресових факторів на продуктивність $і$ фізіологічні функиії свиней на дорощуванні та відгодівлі. 3 цією метою використовували фонди наукової бібліотеки Білочерківського національного аграрного університету, наукові пошукові системи Science-Direct та PиbMеd. Важливим завданням ветеринарного обслу-
} 
говування сучасних комплексів з вирошування свиней є забезпечення оптимальних параметрів мікроклімату, годівля якісними кормами, зниження негативного впливу стресових факторів. Забезпечення належних умов утримання сприяє поліпшенню якісних $i$ кількісних показників продуктивності свиней. У зв'язку з иим вважаємо, шо перспективним напрямком наукових досліджень є вивчення впливу окремих стресових факторів та їхніх комбінацій на організм свиней і пошук методів їх корекції.

Ключові слова: стрес, свині, поведінка, продуктивність, методи, умови.

\section{Вступ}

При наявності численної літератури щодо вивчення впливу стресових факторів на організм свиней, велика кількість питань залишається невирішеними. Складність вивчення впливу стресових факторів на організм полягає, по перше, у великій кількості самих стресорів і їх можливих поєднань, по друге - в різноманітті проявів фізіологічних та поведінкових реакцій тварини. Так, реактивність тварин може залежати від їх виду, віку, породи, сезону року і навіть географічного розташування (Borell et al., 2007; Fragomeni et al., 2016). Також найбільш чутливими до впливу стресових факторів зазвичай $\epsilon$ важливі фізіологічні та поведінкові функції, показники продуктивності та репродуктивного процесу. Наприклад, у свиноматок за стресових станів насамперед порушуються овуляція, прояв статевої поведінки, процес імплантації ембріона тощо (Einarsson et al., 2008). Також результати досліджень, проведених іншими авторами (Wellock et al., 2003; Cervantes et al., 2016; da Fonseca de Oliveira et al., 2019; Čobanović et al., 2020), вказують на те, що продуктивність поросят різного віку зазвичай суттєво знижується (12-28 \%) за впливу стресорів різного генезу (тепловий, соціальний, сезонний).

Тому метою досліджень було ознайомитися 3 сучасними літературними даними щодо особливостей впливу стресових факторів на продуктивність і фізіологічні функції свиней.

\section{Матеріал і методи досліджень}

Під час написання цієї оглядової статті ми ознайомилися з даними сучасних наукових досліджень щодо впливу стресових факторів на продуктивність і фізіологічні функції свиней на дорощуванні та відгодівлі. 3 цією метою використовували фонди наукової бібліотеки Білоцерківського національного аграрного університету, наукові пошукові системи Science-Direct та PubMed.

\section{Результати та їх обговорення}

Під час аналізу літературних даних було встановлено, що вагомим патогенетичним механізмом впливу стресових факторів на організм свиней $є$ порушення функцій шлунково-кишкового тракту. Зокрема, Z. Zhou та співавт. (Zhou et al., 2019) досліджували зміни в ободовій кишці поросят під час відлучки. Авторами було встановлено, що процес відлучення у поросят суттєво впливає на ріст і розвиток ободової кишки, що може бути пов'язано зі зміною концентрації коротколанцюгових жирних кислот в товстій кишці.
Yu J. et al. (2010) наголошують, що проблема теплового стресу у свиней загострюється в умовах глобального потепління, особливо в літній період, коли чутливість цих тварин до високої зовнішньої температури значно підвищується. Автори вивчали зміни експресії генів у тонкому кишечнику свиней за впливу теплового стресу. Було встановлено, що разом 3 підвищенням ректальної та поверхневої температури і рівня кортизолу в сироватці крові у дослідних свиней значно зміцнювалася експресія генів білків тонкого кишечнику. Зокрема, в дванадцятипалій та порожній кишках було виявлено 203 дерегульованих гени. Вплив стресу на генетичний апарат тонкого кишечнику свиней підтверджується і даними X. Тао та Z. Xu (Тао \& Xu, 2010). Авторами було встановлено, що miRNA транскріптома значно відрізнялася у підсисних та відлучених поросят і така різниця підвищувалася з віком тварини.

Інші автори (Pearce et al., 2012; 2013; 2014) встановили, що вплив теплового стресу у свиней супроводжується зменшенням кількісних (привага) та якісних (співвідношення жирів та білків) показників продуктивності. Це відбувається за рахунок зниження апетиту (Pearce et al., 2014; Morales et al., 2014), порушення проникності тонкого кишечнику (Pearce et al., 2012; 2014; Morales et al., 2016) та метаболізму поживних речовин після їх всмоктування (Рearce et al., 2013). В результаті збільшується проникність ендотоксинів в циркуляторне русло та чутливість тварин до розвитку запальних реакцій (Pearce et al., 2013).

Horn N. та співавт. (Horn et al., 2014) досліджували вплив гострого обмеження кількості води та корму у свиней на привагу, характеристики кишечнику та стресові маркери сироватки крові у відлучених поросят. Було встановлено, що 24-годинний дефіцит корму або води під час відлучення негативно впливає на показники росту, функціональні особливості тонкого кишечнику (підвищення проникності) та рівень маркерів стресу в сироватці крові безпосередньо після стресового впливу та протягом всього періоду відлучення. Підвищення проникності кишечнику, в тому числі для окремих поживних речовин (зокрема глюкози), у свиней за теплового стресу констатували S. C. Pearce та співавт. (Pearce et al., 2014).

Метою досліджень M. Le Sciellour та співавт. (Le Sciellour et al., 2019) було вивчити зміни складу фекальної мікробіоти у поросят на дорощуванні за хронічного і гострого теплового стресу та вплив названих змін на продуктивність і фізіологічні показники терморегуляції. Досліджували потомство 10 кнурів сімейства F1 кросів великих білих та креолевих свиней. У віці від 11 до 23 тижнів 558 та 564 тварини вирощували в умовах помірного та тропічного клімату відповідно. За вивчення складу фекальної мікробіоти свиней фенотипували на дві групи - першу (Turicibacter- 
Sarcina-Clostridium sensu stricto) та другу (Lactobacillus-dominated ентеротип). Було встановлено, що фекальна мікробіота значно відрізнялася у свиней за утримання в умовах помірного та тропічного клімату й у тварин після теплового стресу (утримання протягом 3 тижнів за зовнішньої температури $\left.29^{\circ} \mathrm{C}\right)$. При цьому свині $з$ першим ентеротипом були краще адаптовані до умов теплового стресу, мали вищу продуктивність та виявляли менші коливання температури тіла. Автори зробили висновок про те, що склад мікробіоти кишечнику може залежати від стресчутливості тварин і його можна використовувати як біомаркер адаптативних можливостей організму поросят.

Дослідження, проведені Е. Ј. Маyorga та співавт. (Mayorga et al., 2020), показали, що тепловий стрес знижує показники приросту за рахунок впливу на функції органів травлення та метаболічні процеси в організмі тварин. Автори вважають, що важливим патогенетичним фактором вищезазначених змін в організмі тварин $є$ порушення функції шлунковокишкового тракту. Тепловий стрес викликає порушення цілісності кишкового бар'єру, в результаті чого виникають місцеві та системні запальні реакції. На думку авторів, це викликає зміни функціональної активності імунної системи та порушення репродуктивних функцій тварин.

Дані, отримані S. C. Pearce та співавт. (Pearce et al., 2015), підтверджують, що тепловий стрес може негативно впливати на цілісність кишечнику та засвоєння поживних речовин організмом тварин. Проведені ними дослідження встановили, що додавання до корму дієтичного цинку нормалізує бар'єрну функцію кишечнику, сприяє регенерації епітелію кишечнику й за рахунок цього пом'якшує негативний вплив теплового стресу на організм свиней.

F. Liu та співавт. (Liu et al., 2017) досліджували вплив дієтичного хрому $(\mathrm{Cr})$ на ріст та фізіологічні показники поросят за впливу теплового стресу у свиней на дорощуванні. 3 цією метою 36 поросят було поділено на дві групи (1 група отримувала звичайний раціон, а 2 - звичайний раціон $з$ додаванням дієтичного хрому). На 14 добу групу свиней, що отримували добавку Cr, піддавали дії теплового стресу. Фізіологічні реакції організму свиней контролювали шляхом вимірювання частоти дихання, ректальної температури, визначення вмісту газів у крові та врахування апетиту тварин. Результати показали, що за додавання $\mathrm{Cr}$ зменшувались піки підвищення рівня ректальної температури та частоти дихання у дослідних свиней. Однак додавання $\mathrm{Cr}$ не сприяло відновленню середньодобового споживання корму свинями в умовах теплового стресу. Підвищення середньодобового приросту в дослідній групі автори пояснюють зниженням індексу інсулінорезистентності, що призвело до кращого засвоєння поживних речовин корму.

Аналіз наведених результатів досліджень свідчить про те, що вплив стресу є важливим патогенетичним фактором порушення функції шлунково-кишкового тракту свиней. Зокрема, було встановлено, що різні стресові фактори окремо або в комбінації викликають зменшення всмоктувальної та бар'єрної функції ки- шечнику, зміни складу мікробіоти товстого кишечнику та порушення засвоєння поживних речовин. Очевидно, названі зміни в організмі тварин потенційно можуть призводити до порушення анаболізму і відповідно втрати продуктивних якостей свиней.

Так, L. Zhao та співавт. (Zhao et al., 2018) вивчали вплив теплового стресу на метаболізм скелетних м'язів. Авторами було встановлено, що стрес сприяв неповному окисленню жирних кислот скелетних м'язів, окисленню глюкози та знижував метаболізм.

Іншими авторами (Wellock et al., 2004; Renaudeau et al., 2011), було встановлено, що важливим фактором, який підвищує чутливість до стресів у свиней, $є$ варіативність живої ваги та продуктивності у тварин, що утримуються в одній групі. Чим більшою є різниця живої ваги і продуктивності у поросят, тим чутливіші тварини цієї групи до впливу стресових факторів. Такі результати автори пояснюють загостренням ієрархічних взаємовідносин у свиней однієї групи з різною живою масою і продуктивністю.

Метою дослідження М. А. Sutherland та співав. (Sutherland et al., 2006) було визначити, чи відрізняються певні фізіологічні реакції організму на хронічні стресові фактори у різних порід свиней (Ландрас, Мейшан, Йоркшир). Свиней різних порід віком до 21 дня відлучили від свиноматок та утримували їх в одинакових стандартних умовах. У віці 49 днів свиней поділили на дві групи (дослідна і контрольна). Дослідну групу піддавали стресу (спека, скупчення та змішування), контрольна група утримувалась з однолітками без стресового впливу. Відбирали зразки крові на 1, 7 i 14 добу для визначення концентрації кортизолу та імунних показників. Авторами встановлено, що порода та характер стресового чинника не впливали на фізіологічні показники свиней. Разом 3 тим було встановлено, що соціальний статус тварин впливав на їх імунну відповідь за впливу тепла, змішування та підвищення щільності утримання свиней. Так, за стресового впливу в домінантних тварин виявляли підвищення кількості лейкоцитів, нейтрофілів та активності фагоцитозу порівняно з субординантними свинями.

Poullet N. та співав. (Poullet et al., 2019) i White R. R. зі співав. (White et al., 2015) вивчали вплив короткочасного обмеження кількості кормів та подальшим відновленням об'єму раціону на продуктивність, метаболізм і порідну відмінність у свиней. Досліджували велику білу породу, яка характеризується високою продуктивністю та креольську, яка пристосована до тропічних умов. Під час експерименту враховували добовий приріст свиней, показники температури, зміни рівня гормонів плазми крові та їх метаболітів. Було встановлено, що для всіх показників різниця у відповіді організму між двома породами була незначною. Незалежно від породи, обмеження кормів спричиняло зниження темпів росту та ефективності засвоєння кормів. В обох порід ці зміни швидко компенсувались за відновлення нормального рівня годівлі. За обмеження кормів також знижувалась ректальна та поверхнева температура тіла, частота дихання, рівень сечовини і холестерину у крові. 
Метою досліджень S. M. Cruzen та співавт. (Cruzen et al., 2015) було вивчити вплив тривалого теплового стресу в пренатальний та постнатальний періоди на продуктивність і склад туші свиней на відгодівлі. Під час першої та другої половини чи всього періоду вагітності свиноматки піддавались тепловому стресу шляхом утримання за температури $28-34{ }^{\circ} \mathrm{C}$. Було встановлено, що гестаційний тепловий стрес впливав на постнатальні показники температури тіла поросят. Також за дослідження туш тварин, які піддавалися впливу теплового стресу в пренатальний період, було встановлено зменшення маси голови, кісток та інших частин туші щодо маси тіла.

Serviento A. М. та співавт. (Serviento et al., 2020) i Ross J. W. та співав. (Ross et al., 2017) дослідили вплив хронічного пренатального стресу у свиней, вирощених у постнатальному термонейтральному середовищі та за теплового стресу. Автори встановили, що свині, які піддавалися пренатальному тепловому стресу, мали вищу загальну та поверхневу температуру. В постнатальний період знижувалася ефективність росту, збільшувалася ступінь ожиріння туші, особливо у свиней, яких раніше піддавали тепловому стресу і в пренатальний період. Також були встановлені зміни функції щитовидної залози та фізіологічних показників. На думку авторів, це свідчить про знижену толерантність і дисипаційну здатність свиней, які перенесли хронічний пренатальний тепловий стрес.

Telles F. G. та співавт. (Telles et al., 2016) провели дослідження впливу місцевої анестезії під час кастрації на продуктивність поросят на відгодівлі. Вони встановили, що тварини, які отримували анестезію, мали більший приріст ваги, ніж тварини, кастровані без анестезії. Також вплив кастрації на продуктивність свиней досліджували M. Holinger та співавт. (Holinger et al., 2018). Вони оцінили вплив хронічного стресу на некастрованих та кастрованих свинейсамців. Також автори встановили, що сама кастрація тварин суттєво впливала на характеристики туші та властивості жирової тканини. В некастрованих тварин була вищою продуктивність, але рівень хронічної стресової реакції в завершальний період відгодівлі не відрізнявся від такого у кастрованих самців.

Метою дослідження Н. Valpotić та співавт. (Valpotić et al., 2013) було оцінити ефективність згодовування відлученим поросятам поліоксиетиленуполіоксипропілену (ПОЕ-ПОП) у вигляді одноразової пероральної дози. Під час дослідження враховували продуктивність, приріст маси тіла, кількість спожитого корму та коефіцієнт його перетравності, системні та травні імунні параметри. Автори зробили висновок про те, що згодовування ПОЕ-ПОП сприяє підвищенню циркуляції імунних клітин і завдяки його здатності впливати на асоційовані з кишечником лімфоїдні тканини, які, як відомо, сприяють розвитку більш толерантної, аніж захисної імунної відповіді.

Зокрема, L. V. Scroggs та співавт. (Scroggs et al., 2002) зазначають, що транспортування суттєво не впливало на якісні та кількісні показники свиней на відгодівлі.
Schwerin М. та співав. (Schwerin et al., 2002) встановили, що склад кормів впливає на експресію генів асоційованих із вираженням фізіологічних реакцій за оксидативного стресу у свиней. На нашу думку, це свідчить про те, що можуть існувати ефективні дієтичні протоколи боротьби зі стресовими станами у цього виду тварин.

White Н. М. та співавт. (White et al., 2008) у своїх дослідах встановили, що під час утримання свиней при температурі вищій, ніж у термонейтральній зоні, знижуються їхні добові прирости та якісні показники туші. Також було встановлено, що зменшення щільності утримання тварин може бути ефективним засобом для зменшення негативних наслідків температурного стресу у свиней на дорощуванні.

Отже, наведені вище результати свідчать про те, що за впливу стресових факторів зменшується середньодобовий приріст у свиней. Це відбувається за рахунок зниження апетиту, порушення проникності тонкого кишечнику та метаболізму поживних речовин після їх всмоктування. Також було виявлено, що стрес може призводити до неповного окислення жирних кислот м'язів, порушення процесів окислення глюкози та зниження метаболізму.

Результати досліджень інших авторів вказують на те, що стресові фактори мають вплив також на багато інших органів і систем. Зокрема, Т. Т. Huynh та співавт. (Huynh et al., 2005) досліджували вплив відносної вологості та високої температури навколишнього середовища на фізіологічні реакції та продуктивність свиней. Під час досліду використовували 12 груп (10 свинок на групу). Тварин утримували в окремих загонах-камерах 3 регульованим мікрокліматом та повітрообміном. Мікроклімат у камерах був запрограмований таким чином, що температура залишалася постійною протягом доби. Тварини мали вільний доступ до корму та води. Кожного дня температуру підвищували на 2 градуси (від $16^{\circ} \mathrm{C}$ до $32^{\circ} \mathrm{C}$ ). Відносна вологість повітря підтримувалась на рівні 50, 65 або 80 \%. Під час досліду враховували частоту дихання, ректальну та поверхневу температуру й інтенсивність споживання корму. Було встановлено, що температура навколишнього середовища сильно впливає на фізіологічні показники та продуктивність свиней, тимчасом як відносна вологість має порівняно незначний вплив на організм за теплового стресу у свиней на відгодівлі.

Weller M. М. та співавт. (Weller et al., 2014) дослідили вплив температури та різних рівнів фосфору в раціоні на експресію дев'яти генів, що кодують білки транспортного ланцюга електронів у м'язі свиней Longissimus dorsi. Встановили, що незалежно від фази росту свиней експресія генів знижується за впливу високої температури на організм. Фосфор та висока зовнішня температура $є$ ключовими факторами для регулювання окисного фосфорилювання 3 прямим впливом на продуктивність тварин. Автори зробили висновок про те, що Фосфор та висока температура за утримання свиней, є ключовими факторами для регулювання окисного фосфорилювання з прямим негативним впливом на продуктивність свиней. 
Метою досліджень X. Waltz та співавт. (Waltz et al., 2014) було вивчити, чи може обмеження води впливати на фізіологічні, гематологічні та гемореологічні параметри організму свиней за теплового стресу. Під час досліду проводили щоденні вимірювання споживання води та корму. Вимірювали температуру, частоту дихання, проводили дослідження крові. Було встановлено, що обмеження води не впливало на фізіологічні, гематологічні та гемореологічні показники. Автори зазначили, що адаптація організму до гострого теплового стресу супроводжується значними гематологічними та гемореологічними змінами. Під час теплового стресу збільшувалися кількість ретикулоцитів, гематокрит та ступінь агрегації еритроцитів. Крім того, у дослідних тварин спостерігали збільшення деформації еритроцитів і зменшення в'язкості крові та кількості спожитого корму.

Turin L. та співавт. (Turin et al., 2019) досліджували рівень різних цитокінів та ядерного фактора каппа В у поросят після відлучення. Під час досліду враховували приріст свиней, ураження шкіри, рівень цитокінів в крові та експресію ядерного фактора каппа В. Було встановлено підвищення у дослідних свиней рівня експресії двох цитокінів із протизапальним ефектом, а саме інтерлейкіну та інтерферону-гамма. Також у поросят після відлучення спостерігали збільшення кількості ураження шкіри травматичного походження.

Kuwahara М. та співавт. (Kuwahara et al., 2004) дослідили вплив попарного утримання на добові ритми серцебиття та вегетативну нервову діяльність у мініатюрних свиней. Для цього спочатку свиней утримували індивідуально, потім попарно протягом наступних 3 тижнів. Встановлено, що при індивідуальному утриманні мініатюрних свиней частота серцевих скорочень та вегетативна нервова діяльність були рівномірними протягом доби. Коли свиней утримували попарно, частота серцевих скорочень та нерівномірність добового ритму значно збільшувалися. Хоча ці зміни мали тенденцію до поступового відновлення до початкових рівнів, але не досягали їх навіть через 2 тижні після індивідуального утримання. Автори зробили висновок про те, що мініатюрним свиням потрібно щонайменше 2 тижні, щоб адаптуватися до різних умов утримання. Крім того, на їхню думку, спектральний аналіз потужності варіабельності серцевого ритму може бути корисним методом дослідження впливу стресових факторів на організм свиней.

За даними W. Yuan та співавт. (Yuan et al., 2019), помірна гіпотермія може сприяти лімітованому захисту органів, які перебувають в патологічному стані внаслідок порушення мікроциркуляції крові. Однак гіпотермія за нормального стану тканин негативно впливає на їх фізіологічний стан.

Метою дослідження Н. Wooten та співавт. (Wooten et al., 2019) було вивчити вплив введення агоніста глюкокортикоїдних рецепторів на ефективність росту, показники імунної функції та цілісність кишечника у поросят за раннього відлучення. Було встановлено, що введення агоніста глюкокортикоїдних рецепторів покращує ефективність росту свиней за раннього відлучення. Автори вважають, що такий вплив обумовлюється частково за рахунок пом'якшення негативних наслідків системного запалення. Однак вони звертають увагу, що вивчення повного механізму дії агоністів глюкокортикоїдних рецепторів на цілісність бар'єру за впливу стресових факторів у свиней вимагає подальших досліджень.

Таким чином, наведені вище результати вказують на те, що вплив стресових факторів виявляє комплексний патологофізіологічний вплив на організм свиней. Зокрема, дослідники відмічали зрушення систем мікроциркуляції крові, міжклітинного взаємозв'язку та факторів імунного захисту.

Разом $з$ тим важливим індикатором впливу стресових факторів на організм тварини є іiі поведінка. У зв'язку з цим у спеціальній науковій літературі значна увага приділяється вивченню змін поведінки тварин за дії стресових чинників різного походження.

Sutherland М. А. та співав. (Sutherland et al., 2014) дослідили, що одночасне відлучення від свиноматки та транспортування впливають на поведінкову та фізіологічну реакцію поросят.

Інші автори (Sutherland et al., 2007) досліджували вплив теплового стресу на поведінку, імунну реактивність та продуктивність свиней за інтраназального щеплення проти вірусу репродуктивного та респіраторного синдрому свиней (РРС). Було встановлено, що рівень імунної реактивності (наявність щеплення) суттєво впливає на фізіологічні та поведінкові показники і продуктивність свиней за теплового стресу. У щеплених свиней за теплового стресу частково нівелюється його негативний вплив на фізіологічні показники та продуктивність тварин.

Schrøder-Petersen D. L. Ta Simonsen H. B. (SchrøderPetersen \& Simonsen, 2001) стверджують, що кусання хвоста $\epsilon$ важливим показником оцінки впливу стресових факторів на здоров'я та добробут свиней на відгодівлі. Klein S. та співавт. (Klein et al., 2016) дослідили, чи впливає рання соціалізація поросят (можливість змішування 3 поросятами з інших гнізд під час підсисного періоду) на подальшу поведінку та ризик кусання хвоста у свиней на відгодівлі. Автори зробили висновок про те, що рання соціалізація підвищує добробут поросят у загонах заохочуючи ігрову поведінку. Зокрема, було встановлено, що рання соціалізація зменшує агоністичну поведінку поросят після відлучення, однак значимого зменшення випадків кусання хвоста виявлено не було.

Одночасний вплив кількох екологічних стресфакторів (підвищений рівень механічного шуму, атмосферного аміаку, низька інтенсивність світла) на організм поросят вивчали Е. А. О'Connor та співавт. (O'Connor et al., 2010). Реакцію свиней оцінювали за зміною фізіологічних, виробничих та поведінкових показників. На думку авторів, дисорганізація взаємозв'язку гіпоталамус-гіпофіз-наднирники за комплексного впливу екологічних стрес-факторів призводить до зниження регуляції вироблення кортизолу. При цьому в уражених свиней виявляють порушення фізіологічних показників, зменшення ігрової поведінки та зниження продуктивності. 
Катехоламіни є важливими факторами протимікробного захисту тварин. Зокрема, залпове виділення катехоламінів під час стресових станів сприяє стимуляції реактивної відповіді макроорганізму на дію мікроорганізмів різного походження (Lyte \& Lyte, 2019).

Lebret B. та співавт. (Lebret et al., 2006) дослідили вплив звичайного (повністю решітчаста підлога в клітці) і альтернативного (підстилка $з$ тирси з вільним доступом на відкриту територію) утримання свиней на їх поведінку, вміст катехоламінів і кортизолу в сечі та показники крові відразу після забою. Автори встановили, що альтернативне утримання не впливало на поведінку свиней під час забою, вміст катехоламінів і кортизолу в сечі та показники крові у дослідних свиней. Також було встановлено, що свині за альтернативного утримання мали більший середньодобовий приріст маси тіла та кращі якісні показники м'яса після забою.

Jong I. C. та співавт. (de Jong et al., 1998) вивчали вплив збагачення навколишнього середовища (додавання соломи в клітки) на фізіологічні показники та поведінку свиней на відгодівлі за впливу різних стресових факторів. Встановили, що свині, які утримуються в звичайних умовах, мали більше маніпулятивних соціальних контактів (в тому числі агресивних), ніж свині за утримання в збагаченому середовищі. Водночас фізіологічні реакції на стресові фактори були однаковими для свиней обох груп. Але за додавання соломи у свиней були значно нищими концентрація кортизолу в слині та загальна температура тіла. На думку авторів, це вказує на те, що забезпечення свиней соломою позитивно впливає на поведінку та на фізіологічні параметри організму свиней на відгодівлі.

Визначення вмісту амілоїду А та гаптоглобіну у слині як маркерів стресу у свиней вивчали L. Soler та співавт. (Soler et al., 2019). Автори встановили, що значно вищі концентрації амілоїду А в слині були отримані в ізольованих тварин порівняно зі свиньми за групового утримання. Під час короткого автомобільного транспортування зростали рівні кортизолу та амілоїду А в слині. Зокрема, рівень амілоїду А в слині був значно вищим після прибуття на бійню з максимальними значеннями через 30 та 60 хв після розвантаження. Результати дослідників вказують на те, що визначення амілоїду А в слині (а не гаптоглобіну) є потенційним біомаркером для оцінки впливу стресу на організм свиней. Також автори наголошують, що підвищення рівня амілоїду А у слині свиней за впливу стресових факторів є більш тривалим, ніж кортизолу.

Sierżant K. та співавт. (Munsterhjelm et al., 2010) у своїх дослідженнях встановили, що неналежні гігієнічні умови утримання та неякісні корма для відгодівлі свиней негативно впливали на стан окисновідновного метаболізму. На думку авторів, це призводить до зниження імунітету та до сповільнення росту свиней на відгодівлі.

Qu H. i Ajuwon K. M. (Qu \& Ajuwon, 2018) вивчали вплив теплового стресу на метаболом жирової тканини у свиней. Під час дослідження застосували комбі- націю методів рідинної хроматографії та масспектрометрії. Було встановлено, що тепловий стрес підвищує ліпогенез, одночасно пригнічуючи окислення жирних кислот. Автори вказують на корисність аналізу метаболому як методу для визначення впливу теплового стресу на тканини свиней на відгодівлі.

Kouba M. та співавт. (Kouba et al., 2001) дослідили вплив хронічного теплового стресу на свиней під час відгодівлі. Вони встановили, що висока температура посилює метаболізм ліпідів у печінці (вироблення ліпопротеїдів дуже низької щільності) і в жировій тканині (активність ліпопротеїнової ліпази). Таким чином поліпшується поглинання і зберігання тригліцеридів плазми крові свиней, що призводить до збільшення відкладення жиру у сполучній тканині тварин.

Дослідження, проведені Cervantes M. та співавт. (Cervantes et al., 2017), вказують на те, що висока температура навколишнього середовища впливає на показники температури тіла та засвоєння вільних амінокислот у свиней на відгодівлі. При цьому напрям такого впливу залежить від варіативності добових змін зовнішньої температури.

Отже, результати наведених досліджень свідчать про те, що стресові фактори на організм свиней на дорощенні впливають на поведінку i фізіологічні параметри тварин, що негативно відображається на їхніх продуктивних якостях.

Під час вивчення впливу стресових факторів на організм тварин окремі автори звертають увагу на особливості реактивності організму тварин залежно від їх початкового фізіологічного та клінічного стану.

Seelenbinder K. М. та співавт. (Seelenbinder et al., 2018) вивчали поєднаний вплив на організм свиней вірусної інфекції (репродуктивний і респіраторний синдром) та температурного стресу. Було встановлено, що реакція організму свиней дво-тримісячного віку на поєднаний вплив цих двох факторів не відрізняється від такої за окремого їх використання.

Метою досліджень С. Т. Larson та співавт. (Larson et al., 1985) було визначити вплив соціального стресу на чутливість свиней до стафілококової інфекції. 3 цією метою поросят поділили на дві групи. Поросят першої групи після відлучення не змішували з тваринами 3 інших груп, а другу компонували тваринами 3 різних гнізд. Було встановлено, що поросята другої дослідної групи (вищий рівень соціального стресу) були стійкішими до стафілококової інфекції, ніж тварини першої дослідної групи. На думку авторів, це свідчить про те, що певні рівні стресових станів можуть мати позитивний вплив на імунобіологічну реактивність поросят після відлучення.

Аналіз результатів наведених досліджень свідчить про те, що в останні роки велика кількість наукових досліджень спрямована на вивчення впливу стресових факторів на організм свиней (Wellock et al., 2004; Renaudeau et al., 2011; Pearce et al., 2012; 2013; 2014; Mayorga et al., 2020). Зокрема, встановлено, що вплив стресових факторів на свиней на дорощенні та відгодівлі призводить до порушення функціонування шлунково-кишкового тракту (Yu et al., 2010; Тао \& Xu, 
2010; Zhou et al., 2019), неповного зрушення окислення жирних кислот і глюкози, зниження процесів метаболізму (Zhao et al., 2018).

Також багато вчених зауважують негативний вплив стресових факторів на свиней на відгодівлі, їхню поведінкову та фізіологічну реакцію (Sutherland et al., 2014), добробут (Schrøder-Petersen \& Simonsen, 2001), імунну реактивність (Sutherland et al., 2007) тощо.

Таким чином, за стресових факторів на організм свиней порушується гомеостаз і змінюються їхні поведінкові реакції. На нашу думку, важливим елементом сучасних технологій у свинарстві $€$ зменшення впливу стресу на організм свиней. 3 цією метою слід продовжити вивчення ефективності поліпшення умов утримання та комфорту тварин. У зв'язку з цим підвищується актуальність використання принципів добробуту та елементів збагачення навколишнього середовища відповідно до фізіологічних та поведінкових потреб тварин.

\section{Висновки}

1. Вплив стресових факторів на організм свиней призводить до порушення фізіологічних показників організму, зниження продуктивності та підвищення рівня захворюваності тварин.

2. За впливу стресових факторів у свиней відбувається зниження апетиту, порушується проникність тонкого кишечнику та метаболізм поживних речовин після їх всмоктування, що призводить до зменшення середньодобового приросту.

3. Зміни в організмі свиней за різних стресових факторів (окремо чи в комбінації) викликають зменшення всмоктувальної та бар'єрної функції кишечнику, зміни складу мікробіоти товстого кишечнику і порушення засвоєння поживних речовин. За рахунок таких змін в організмі відбувається порушення анаболізму та втрата продуктивних якостей свиней.

4. За дії стресових факторів на організм свиней порушується гомеостаз і змінюються їхні поведінкові реакції. Для зменшення впливу стресу на організм свиней за сучасних технологій вирощування актуально поліпшувати умови утримання, використовувати принципи добробуту та елементи збагачення навколишнього середовища відповідно до фізіологічних та поведінкових потреб тварин.

Важливим завданням ветеринарного обслуговування сучасних комплексів 3 вирощування свиней $є$ забезпечення оптимальних параметрів мікроклімату, годівля якісними кормами, зниження негативного впливу стресових факторів. Забезпечення належних умов утримання сприяє поліпшенню якісних і кількісних показників продуктивності свиней. У зв'язку з цим вважаємо, що перспективним напрямком наукових досліджень $є$ вивчення впливу окремих стресових факторів та їхніх комбінацій на організм свиней i пошук методів їх корекції.
Відомості про конфлікт інтересів. Автори стверджують про відсутність конфлікту інтересів щодо їх вкладу та результатів досліджень.

\section{References}

Borell, E., Dobson, H., \& Prunier, A. (2007). Stress, behaviour and reproductive performance in female cattle and pigs. Hormones and Behavior, 52(1), 130-138. doi: 10.1016/j.yhbeh.2007.03.014.

Cervantes, M., Cota, M., Arce, N., Castillo, G., Avelar, E., Espinoza, S., \& Morales, A. (2016). Effect of heat stress on performance and expression of selected amino acid and glucose transporters, HSP90, leptin and ghrelin in growing pigs. J. Therm. Biol., 59, 69-76. doi: 10.1016/j.jtherbio.2016.04.014.

Cervantes, M., Ibarra, N., Vásquez, N., Reyes, F., Avelar, E., Espinoza, S., \& Morales, A. (2017). Serum concentrations of free amino acids in growing pigs exposed to diurnal heat stress fluctuations. J. Therm. Biol., 69, 69-75. doi: 10.1016/j.jtherbio.2017.06.008.

Čobanović, N., Stajković, S., Blagojević, B., Betić, N., Dimitrijević, M., Vasilev, D., \& Karabasil, N. (2020). The effects of season on health, welfare, and carcass and meat quality of slaughter pigs. Int. J. Biometeorol., 64(11), 1899-1909. doi: 10.1007/s00484-020-01977-y.

Cruzen, S. M., Boddicker, R. L., Graves, K. L., Johnson, T. P., Arkfeld, E. K., Baumgard, L. H., Ross, J. W., Safranski, T. J., Lucy, M. C., \& Lonergan, S. M. (2015). Carcass composition of market weight pigs subjected to heat stress in utero and during finishing. J. Anim. Sci., 93(5), 2587-2596. doi: 10.2527/jas.2014-8347.

da Fonseca de Oliveira, A. C., Vanelli, K., Sotomaior, C. S., Weber, S. H., \& Costa, L. B. (2019). Impacts on performance of growing-finishing pigs under heat stress conditions: a meta-analysis. Vet. Res. Commun., 43(1), 37-43. doi: 10.1007/s11259-018-9741-1.

de Jong, I. C., Ekkel, E. D., van de Burgwal, J. A., Lambooij, E., Korte, S. M., Ruis, M. A., Koolhaas, J. M., \& Blokhuis, H. J. (1998). Effects of strawbedding on physiological responses to stressors and behavior in growing pigs. Physiol. Behav., 64(3), 303-310. doi: 10.1016/s0031-9384(98)00066-3.

Einarsson, S., Brandt, Y., Lundeheim, N., \& Madej, A. (2008). Stress and its influence on reproduction in pigs: A review. Acta Vet. Scand., 50(1), 48. doi: 10.1186/1751-0147-50-48.

Fragomeni, B. O., Lourenco, D. A., Tsuruta, S., Andonov, S., Gray, K., Huang, Y., \& Misztal, I. (2016). Modeling response to heat stress in pigs from nucleus and commercial farms in different locations in the United States. J. Anim Sci., 94(11), 4789-4798. doi: 10.2527/jas.2016-0536.

Holinger, M., Früh, B., Stoll, P., Pedan, V., Kreuzer, M., Bérard, J., \& Hillmann, E. (2018). Long-term effects of castration, chronic intermittent social stress, provision of grass silage and their interactions on performance and meat and adipose tissue properties in growing-finishing pigs. Meat. Sci., 145, 40-50. doi: 10.1016/j.meatsci.2018.05.018. 
Horn, N., Ruch, F., Miller, G., Ajuwon, K. M., \& Adeola, O. (2014). Impact of acute water and feed deprivation events on growth performance, intestinal characteristics, and serum stress markers in weaned pigs. J. Anim. Sci., 92(10), 4407-4416. doi: 10.2527/jas.2014-7673.

Huynh, T. T., Aarnink, A. J., Verstegen, M. W., Gerrits, W. J., Heetkamp, M. J., Kemp, B., \& Canh, T. T. (2005). Effects of increasing temperatures on physiological changes in pigs at different relative humidities. J. Anim. Sci., 83(6), 1385-1396. doi: 10.2527/2005.8361385x.

Klein, S., Patzkéwitsch, D., Reese, S., \& Erhard, M. (2016). Effekte einer frühen Sozialisierung von Ferkeln auf das Verhalten, unter anderem auf das Schwanzbeißen [Effects of socializing piglets in lactation on behaviour, including tail-biting, in growing and finishing pigs]. Tierarztl Prax Ausg G Grosstiere Nutztiere, 44(3), 141-150. doi: 10.15653/TPG-160134.

Kouba, M., Hermier, D., \& Le Dividich, J. (2001). Influence of a high ambient temperature on lipid metabolism in the growing pig. J. Anim. Sci., 79(1), 81-87. doi: $10.2527 / 2001.79181 x$

Kuwahara, M., Tsujino, Y., Tsubone, H., Kumagai, E., Tsutsumi, H., \& Tanigawa, M. (2004). Effects of pair housing on diurnal rhythms of heart rate and heart rate variability in miniature swine. Exp. Anim., 53(4), 303-309. doi: 10.1538/expanim.53.303.

Larson, C. T., Gross, W. B., \& Davis, J. W. (1985). Social stress and resistance of chicken and swine to Staphylococcus aureus challenge infections. Can. J. Comp. Med., 49(2), 208-210. URL: https://pubmed.ncbi.nlm. nih.gov/4016586.

Le Sciellour, M., Zemb, O., Hochu, I., Riquet, J., Gilbert, H., Giorgi, M., Billon, Y., Gourdine, J. L., \& Renaudeau, D. (2019). Effect of chronic and acute heat challenges on fecal microbiota composition, production, and thermoregulation traits in growing pigs1,2. J. Anim. Sci., 97(9), 3845-3858. doi: 10.1093/jas/skz222.

Lebret, B., Meunier-Salaün, M. C., Foury, A., Mormède, P., Dransfield, E., \& Dourmad, J. Y. (2006). Influence of rearing conditions on performance, behavioral, and physiological responses of pigs to preslaughter handling, carcass traits, and meat quality. J. Anim. Sci., 84(9), 2436-2447. doi: 10.2527/jas.2005-689.

Liu, F., Cottrell, J. J., Wijesiriwardana, U., Kelly, F. W., Chauhan, S. S., Pustovit, R. V., Gonzales-Rivas, P. A., DiGiacomo, K., Leury, B. J., Celi, P., \& Dunshea, F. R. (2017). Effects of chromium supplementation on physiology, feed intake, and insulin related metabolism in growing pigs subjected to heat stress. Transl. Anim. Sci., 1(1), 116-125. doi: 10.2527/tas2017.0014.

Lyte, J. M., \& Lyte, M. (2019). Review: Microbial endocrinology: intersection of microbiology and neurobiology matters to swine health from infection to behavior. Animal, 13(11), 2689-2698. doi: 10.1017/S1751731119000284.

Mayorga, E. J., Ross, J. W., Keating, A. F., Rhoads, R. P., \& Baumgard, L. H. (2020). Biology of heat stress; the nexus between intestinal hyperpermeability and swine reproduction. Theriogenology, 154, 73-83. doi: 10.1016/j.theriogenology.2020.05.023.

Morales, A., Cota, S. E., Ibarra, N. O., Arce, N., Htoo, J. K., \& Cervantes, M. (2016). Effect of heat stress on the serum concentrations of free amino acids and some of their metabolites in growing pigs. J. Anim. Sci., 94(7), 2835-2842. doi: 10.2527/jas.2015-0073.

Morales, A., Grageola, F., García, H., Arce, N., Araiza, B., Yáñez, J., \& Cervantes, M. (2014). Performance, serum amino acid concentrations and expression of selected genes in pair-fed growing pigs exposed to high ambient temperatures. J Anim Physiol Anim Nutr (Berl), 98(5), 928-935. doi: 10.1111/jpn.12161.

Munsterhjelm, C., Valros, A., Heinonen, M., Hälli, O., Siljander-Rasi, H., \& Peltoniemi, O. A. (2010). Environmental enrichment in early life affects cortisol patterns in growing pigs. Animal, 4(2), 242-249. doi: 10.1017/S1751731109990814.

O'Connor, E. A., Parker, M. O., McLeman, M. A., Demmers, T. G., Lowe, J. C., Cui, L., Davey, E. L., Owen, R. C., Wathes, C. M., \& Abeyesinghe, S. M. (2010). The impact of chronic environmental stressors on growing pigs, Sus scrofa (Part 1): stress physiology, production and play behaviour. Animal, 4(11), 18991909. doi: 10.1017/S1751731110001072.

Pearce, S. C., Mani, V., Boddicker, R. L., Johnson, J. S., Weber, T. E., Ross, J. W., Baumgard, L. H., \& Gabler, N. K. (2012). Heat stress reduces barrier function and alters intestinal metabolism in growing pigs. J. Anim. Sci., 90(4), 257-259. doi: 10.2527/jas.52339.

Pearce, S. C., Gabler, N. K., Ross, J. W., Escobar, J., Patience, J. F., Rhoads, R. P., \& Baumgard, L. H. (2013). The effects of heat stress and plane of nutrition on metabolism in growing pigs. J. Anim. Sci., 91(5), 108-118. doi: 10.2527/jas.2012-5738.

Pearce, S. C., Mani, V., Weber, T. E., Rhoads, R. P., Patience, J. F., Baumgard, L. H., \& Gabler, N. K. (2013). Heat stress and reduced plane of nutrition decreases intestinal integrity and function in pigs. J. Anim. Sci., 91(11), 5183-5193. doi: 10.2527/jas.2013-6759.

Pearce, S. C., Sanz-Fernandez, M. V., Hollis, J. H., Baumgard, L. H., \& Gabler, N. K. (2014). Short-term exposure to heat stress attenuates appetite and intestinal integrity in growing pigs. J. Anim. Sci., 92(12), 5444-5454. doi: 10.2527/jas.2014-8407.

Pearce, S. C., Mani, V., Boddicker, R. L., Johnson, J. S., Weber, T. E., Ross, J. W., Rhoads, R. P., Baumgard, L. H., \& Gabler, N. K. (2014). Heat stress reduces intestinal barrier integrity and favors intestinal glucose transport in growing pigs. PLoS One, 8(8), 702-715. doi: 10.1371/journal.pone.0070215.

Pearce, S. C., Sanz Fernandez, M. V., Torrison, J., Wilson, M. E., Baumgard, L. H., \& Gabler, N. K. (2015). Dietary organic zinc attenuates heat stress-induced changes in pig intestinal integrity and metabolism. J. Anim. Sci., 93(10), 4702-4713. doi: 10.2527/jas.2015-9018.

Poullet, N., Bambou, J.C., Loyau, T., Trefeu, C., Feuillet, D., Beramice, D., Bocage, B., Renaudeau, D., \& Gourdine, J. L. (2019). Effect of feed restriction and refeeding on performance and metabolism of European and Caribbean growing pigs in a tropical climate. Sci Rep., 9(1), 4878. doi: 10.1038/s41598-019-41145-w.

Qu, H., \& Ajuwon, K. M. (2018). Metabolomics of heat stress response in pig adipose tissue reveals alteration of phospholipid and fatty acid composition during 
heat stress. J. Anim. Sci., 96(8), 3184-3195. doi: $10.1093 /$ jas/sky127.

Renaudeau, D., Gourdine, J. L., \& St-Pierre, N. R. (2011). A meta-analysis of the effects of high ambient temperature on growth performance of growing-finishing pigs. J. Anim. Sci., 89(7), 2220-2230. doi: 10.2527/jas.20103329 .

Ross, J. W., Hale, B. J., Seibert, J. T., Romoser, M. R., Adur, M. K., Keating, A. F., \& Baumgard, L. H. (2017). Physiological mechanisms through which heat stress compromises reproduction in pigs. Mol. Reprod. Dev., 84(9), 934-945. doi: 10.1002/mrd.22859.

Schrøder-Petersen, D. L., \& Simonsen, H. B. (2001). Tail biting in pigs. Vet. J., 162(3), 196-210. doi: $10.1053 /$ tvj1.2001.0605.

Schwerin, M., Dorroch, U., Beyer, M., Swalve, H., Metges, C. C., \& Junghans, P. (2002). Dietary protein modifies hepatic gene expression associated with oxidative stress responsiveness in growing pigs. FASEB J., 16(10), 1322-1324. doi: 10.1096/fj.01-0734fje.

Scroggs, L. V., Kattesh, H. G., Morrow, J. L., Stalder, K. J., Dailey, J. W., Roberts, M. P., Schneider, J. F., \& Saxton, A. M. (2002). The effects of split marketing on the physiology, behavior, and performance of finishing swine. J. Anim. Sci., 80(2), 338-345. doi: $10.2527 / 2002.802338 x$.

Seelenbinder, K. M., Zhao, L. D., Hanigan, M. D., Hulver, M. W., McMillan, R. P., Baumgard, L. H., Selsby, J.T., Ross, J. W., Gabler, N. K., \& Rhoads, R. P. (2018). Effects of heat stress during porcine reproductive and respiratory syndrome virus infection on metabolic responses in growing pigs. J. Anim. Sci., 96(4), 1375-1387. doi: 10.1093/jas/sky057.

Serviento, A. M., Lebret, B., \& Renaudeau, D. (2020). Chronic prenatal heat stress alters growth, carcass composition, and physiological response of growing pigs subjected to postnatal heat stress. J. Anim. Sci., 98(5), doi: 10.1093/jas/skaa161.

Sierżant, K., Perruchot, M. H., Merlot, E., Le Floc'h, N., \& Gondret, F. (2019). Tissue-specific responses of antioxidant pathways to poor hygiene conditions in growing pigs divergently selected for feed efficiency. BMC Vet. Res., 15(1), 341. doi: 10.1186/s12917-0192107-2.

Soler, L., Gutiérrez, A., Escribano, D., Fuentes, M., \& Cerón, J. J. (2019). Response of salivary haptoglobin and serum amyloid A to social isolation and short road transport stress in pigs. Res. Vet. Sci., 95(1), 298-302. doi: 10.1016/j.rvsc.2013.03.007.

Sutherland, M. A., Backus, B. L., \& McGlone, J. J. (2014). Effects of Transport at Weaning on the Behavior, Physiology and Performance of Pigs. Animals (Basel), 4(4), 657-669. doi: 10.3390/ani4040657.

Sutherland, M. A., Niekamp, S. R., Johnson, R. W., Van Alstine, W. G., \& Salak-Johnson, J. L. (2007). Heat and social rank impact behavior and physiology of PRRS-virus-infected pigs. Physiol. Behav., 90(1), 7381. doi: 10.1016/j.physbeh.2006.08.029.

Sutherland, M. A., Niekamp, S. R., Rodriguez-Zas, S. L., \& Salak-Johnson, J. L. (2006). Impacts of chronic stress and social status on various physiological and perfor- mance measures in pigs of different breeds. J. Anim. Sci., 84(3), 588-596. doi: 10.2527/2006.843588x

Tao, X., \& Xu, Z. (2010). MicroRNA transcriptome in swine small intestine during weaning stress. PLoS One, 8(11), e79343. doi: 10.1371/journal.pone.0079343.

Telles, F. G., Luna, S. P., Teixeira, G. L., \& Berto, D. A. (2016). Long-term weight gain and economic impact in pigs castrated under local anaesthesia. Vet. Anim. Sci., 1-2, 36-39. doi: 10.1016/j.vas.2016.11.003.

Turin, L., Torinesi, R., \& Pastorelli, G. (2019). Real-time PCR detection of the effect of postweaning on the expression of cytokines and NF-kB in piglets. J Biol Regul Homeost Agents, 33(6), 1737-1745. doi: $10.23812 / 19-342-A$.

Valpotić, H., Mršić, G., Gršković, B., Špoljarić, D., Kezić, D., Srečec, S., Mataušić-Pišl, M., Lacković, G., Capak, D., Mihelić, D., Vlahović, K., Valpotić, I., Pirkić, A., Andjelinovic, D., \& Popović, M. (2013). Effect of polyoxyethylene and polyoxypropylene nonionic block copolymers on performance and recruitment of immune cell subsets in weaned pigs. Acta. Vet. Scand., 55(1), 54. doi: 10.1186/1751-0147-55-54.

Waltz, X., Baillot, M., Connes, P., Bocage, B., \& Renaudeau, D. (2014). Effects of hydration level and heat stress on thermoregulatory responses, hematological and blood rheological properties in growing pigs. PLoS One, 9(7). doi: 10.1371/journal.pone.0102537.

Weller, M. M., Alebrante, L., Campos, P. H., Saraiva, A., Silva, B. A., Donzele, J. L., Oliveira, R. F., Silva, F. F., Gasparino, E., Lopes, P. S., \& Guimarães, S. E. (2014). Effect of heat stress and feeding phosphorus levels on pig electron transport chain gene expression. Animal, 7(12), 1985-1993. doi: 10.1017/S1751731113001535.

Wellock, I. J., Emmans, G. C., \& Kyriazakis, I. (2003). Predicting the consequences of social stressors on pig food intake and performance. J. Anim Sci., 81(12), 2995-3007. doi: 10.2527/2003.81122995x.

Wellock, I. J., Emmans, G. C., \& Kyriazakis, I. (2004). Modeling the effects of stressors on the performance of populations of pigs. J. Anim. Sci., 82(8), 24422450. doi: $10.2527 / 2004.8282442 x$.

White, H. M., Richert, B. T., Schinckel, A. P., Burgess, J. R., Donkin, S. S., \& Latour, M. A. (2008). Effects of temperature stress on growth performance and bacon quality in grow-finish pigs housed at two densities. J. Anim. Sci., 86(8), 1789-1798. doi: 10.2527/jas.20070801.

White, R. R., Miller, P. S., \& Hanigan, M. D. (2015). Evaluating equations estimating change in swine feed intake during heat and cold stress. J. Anim. Sci., 93(11), 5395-5410. doi: 10.2527/jas.2015-9220.

Wooten, H., McGlone, J. J., Wachtel, M., Thompson, G., Rakhshandeh, A. R., \& Rakhshandeh, A. (2019). A glucocorticoid receptor agonist improves postweaning growth performance in segregated earlyweaned pigs. Animal, 13(9), 1972-1981. doi: $10.1017 /$ S1751731118003634.

Yu, J., Yin, P., Liu, F., Cheng, G., Guo, K., Lu, A., Zhu, X., Luan, W., \& Xu, J. (2010). Effect of heat stress on the porcine small intestine: a morphological and gene expression study. Comp. Biochem. Physiol. A Mol. 
Integr. Physiol., 156(1), 119-128. $\quad$ stress decreases metabolic flexibility in skeletal musdoi: 10.1016/j.cbpa.2010.01.008.

Yuan, W., Wu, J. Y., Zhao, Y. Z., Li, J., Li, J. B., Li, Z. H., \& Li, C. S. (2019). Effects of Mild Hypothermia cle of growing pigs. Am. J. Physiol. Regul. Integr. Comp. Physiol., 315(6), 1096-1106. doi: 10.1152/ajpregu.00404.2017.

on Cardiac and Neurological Function in Piglets Under Pathological and Physiological Stress Conditions. Ther. Hypothermia Temp. Manag., 9(2), 136-145. doi: 10.1089/ther.2018.0026.

Zhao, L., McMillan, R. P., Xie, G., Giridhar, S. G. L. W., Baumgard, L. H., El-Kadi, S., Selsby, J., Ross, J., Gabler, N., Hulver, M. W., \& Rhoads, R. P. (2018). Heat

Zhou, Z., Zhang, J., Zhang, X., Mo, S., Tan, X., Wang, L., Li, J., Li, Y., Ding, X., Liu, X., Ma, X., Yang, H., \& Yin, Y. (2019). The production of short chain fatty acid and colonic development in weaning piglets. J. Anim. Physiol. Anim. Nutr. (Berl)., 103(5), 1530 1537. doi: $10.1111 /$ jpn.13164. 